\title{
Correlation Between Mobile Phone Use Intensity With Carpal Tunnel Syndrome
}

\author{
Safira Disha' ${ }^{1}$, Aida Fitri' ${ }^{2}$ Chairil Amin Batubara ${ }^{2}$, Khairul Putra Surbakti ${ }^{2}$ \\ ${ }^{1}$ Faculty of Medicine Universitas Sumatera Utara, Indonesia \\ ${ }^{2}$ Department of Neurology, Faculty of Medicine Universitas Sumatera Utara, Indonesia
}

\begin{abstract}
Background. High intensity of mobile phone use can cause Carpal Tunnel Syndrome. Repeated wrist positions and movements cause increase pressure in carpal tunnel, that condition can compress the median nerve. Objectives. To determine the correlation between mobile phone use intensity and Carpal Tunnel Syndrome in Medical Faculty North Sumatera University Student. Methods. This research used an observational analytic design with cross sectional method. The sample were 417 Medical Faculty North Sumatera University students who met the inclusion criteria and were not included in the exclusion criteria. The instrument of this research were Mobile Phone Use Questionnaire and Indonesian version of the Boston Carpal Tunnel Questionnaire. The research results were analyzed using the Statistical Package for Social Science application with the Rank Spearman Correlation Test. Results. Based on the Rank Spearman Correlation test, obtained $\mathrm{p}<0,0001$ which stated that there was a correlation between mobile phone use intensity with Carpal Tunnel Syndrome. The correlation coefficient of 0.177 indicated very weak correlation and correlation between two variables was unidirectional. Conclusion. There was correlation between mobile phone use intensity with Carpal Tunnel Syndrome in Medical Faculty North Sumatera University Student.
\end{abstract}

Keyword: Intensity, Mobile Phone, Carpal Tunnel Syndrome

Received date month year $\mid$ Revised date month year $\mid$ Accepted date month year

\section{Introduction}

Development of information technology in Indonesia in this era is increasing. Based on the Indonesia Digital survey in 2019, the average Indonesian person spends time playing the internet for 8 hours 36 minutes per day, social media 3 hours 26 minutes, television 2 hours 52 minutes and streaming music 1 hour 22 minutes [1]. This habit can have both positive and negative effects. One of negative effects of electronic media overuse is Carpal Tunnel Syndrome. Carpal Tunnel Syndrome is defined as impaired motor or sensory function of the median nerve as it passes

*Corresponding author at: Faculty of Medicine Universitas Sumatera Utara, Indonesia 
through the carpal tunnel. It is caused by intrinsic swelling of the median nerve or extrinsic compression of the median nerve by one of the many structures around the wrist [2].

The purpose of this study was to determine the correlation between mobile phone use intensity with Carpal Tunnel Syndrome especially among Medical Faculty North Sumatera University students, because Carpal Tunnel Syndrome research was generally conducted among workers with other risk factors such as using laptops / computers. Carpal Tunnel Syndrome can be caused by risk factors such as prolonged hand holding in one position, repeated use of the flexor muscles, and exposure to vibrations [3]. Normal pressure in carpal tunnel is between 2 and $10 \mathrm{mmHg}$. The pressure changes can be caused by wrist movement, with extension increasing the pressure by 10 times and flexion by 8 times. When the wrist is flexed, the pressure reaches a value of $94 \mathrm{mmHg}$ and becomes $110 \mathrm{mmHg}$ when the wrist is extended. Pathological changes in the ligaments around the nerves including changes in the number and flexibility of connective tissue are also considered to be the basis for increased pressure. Increased pressure of the carpal tunnel can cause ischemic compression of the median nerve [4]. According to study using mobile phone, computer, electronic tablet and laptop can increase the risk of Carpal Tunnel Syndrome. This relates to hand position and repetitive movements such as tapping, swiping and scrolling on electronic device screens [5].

\section{Methodology}

This research used an observational analytic design with cross sectional method. This research was conducted online via google form due to the COVID-19 pandemic. The time of this research was July to December 2020. This research has obtained Ethical Clearance from the Ethical Commission of the Medical Faculty North Sumatera University. The sample of this study were all Medical Faculty North Sumatera University Students batch 2017-2019 who own or use a mobile phone and willing to be a respondent and complete the questionnaire. The subjects will be excluded if they have chronic diseases such as diabetes mellitus, autoimmune, malignancy, a history of hand trauma, impaired liver and kidney function, and using anti-tuberculosis drugs. Of the 759 students, 417 students were eligible and willing to take part in this research.

This study used primary data sourced from questionnaires. The questionnaire to assessed the mobile phone use intensity was obtained from Hermansyah research in 2018 [6]. This questionnaire contained 20 questions about the frequency and duration mobile phone use intensity in daily life that has been tested for validity previously. The questionnaire to assessed the symptoms of Carpal Tunnel Syndrome was taken from Cindy research in 2019 [7]. This questionnaire was developed from the Boston Carpal Tunnel Questionnaire which has been tested for reliability. There were 11 questions on the Boston Carpal Tunnel Questionnaire regarding symptoms of pain, numbness, tingling and weakness in the hands in the last 2 weeks. Data analysis in this research used Rank Spearman correlation test because the data were numerical in scale and not normally distributed. The data collected processed and analyzed using the SPSS (Statistic Package for Social Science) application. 


\section{Results and Discussion}

Of the 417 respondents consist 140 male and 277 female and the largest percentage of respondent's age was 20-22 years. Demographic characteristic are presented in Table 1.

Table 1 Demographic Characteristic

\begin{tabular}{lll}
\hline $\begin{array}{l}\text { Demographic } \\
\text { Characteristic }\end{array}$ & $\begin{array}{l}\text { Frequency } \\
(\mathbf{n = 4 1 7 )}\end{array}$ & $\begin{array}{l}\text { Percentage } \\
(\%)\end{array}$ \\
\hline Age & & \\
$17-19$ & 134 & 32 \\
$20-22$ & 275 & 66 \\
$23-25$ & 8 & 2
\end{tabular}

\section{Gender}

\begin{tabular}{lll} 
Male & 140 & 33,6 \\
Female & 277 & 66,4 \\
Class & & \\
2017 & 203 & 48,7 \\
2018 & 116 & 27,8 \\
2019 & 98 & 23,5 \\
\hline
\end{tabular}

Based on Table 2, the majority students used mobile phone with high intensity in daily life. And based on Table 3, the majority of students experienced mild symptoms and females experienced more symptoms than males.

Table 2 Mobile Phone Use Intensity

\begin{tabular}{lll}
\hline Intensity & $\begin{array}{l}\text { Frequency } \\
(\mathbf{n = 4 1 7 )}\end{array}$ & Percentage (\%) \\
\hline Moderate & 24 & 5,8 \\
High & 393 & 94,2 \\
\hline
\end{tabular}

Table 3 Symptoms of Carpal Tunnel Syndrome

\begin{tabular}{llll}
\hline Gender & $\begin{array}{l}\text { No } \\
\text { symptom }\end{array}$ & Mild & Moderate \\
\end{tabular}




\begin{tabular}{lcccccc}
\hline & $\mathrm{n}$ & $\%$ & $\mathrm{n}$ & $\%$ & $\mathrm{n}$ & $\%$ \\
Male & 63 & 45 & 75 & 53,6 & 2 & 1,4 \\
Female & 98 & 35,4 & 169 & 61 & 10 & 3,6 \\
\hline
\end{tabular}

Based on Table 4, there was a correlation between the mobile phone use intensity with Carpal Tunnel Syndrome in Medical Faculty North Sumatera University students batch 2017-2019 (p $<0,0001$ ) and the correlation was very weak (correlation coefficient of 0.177 ). Positive correlation value stated that the Correlation between two variables was unidirectional. Therefore, the higher mobile phone use intensity has greater risk to Carpal Tunnel Syndrome.

Table 4 Rank Spearman Correlation Test

\begin{tabular}{lll}
\hline \multicolumn{3}{c}{ Carpal Tunnel Syndrome } \\
\hline Mobile Phone Use Intensity & $\mathrm{r}$ & 0,177 \\
& $\mathrm{p}$ & 0,000 \\
\hline
\end{tabular}

The results of Rank Spearman correlation test analysis showed that there was correlation between mobile phone use intensity and Carpal Tunnel Syndrome. From previous study, there were differences in the ultrasound images before and after mobile phone use. The ultrasound results showed that the area of the median nerve and the space in the carpal tunnel was reduced after using mobile phone resulting soft tissue pressing on the median nerve. In addition, the distance between the upper part and the base of the median nerve to the os lunatum increases. Based on this, it is assumed that there is thickening of soft tissues such as muscles and ligaments due to the mobile phone use [8]. Research in 2019 stated that there was a relationship between internet use and Carpal Tunnel Syndrome incidence in students of the Faculty of Computer Science, University of Klabat. Using internet with a long duration, repeated frequency and the position of the hand that is maintained for a long time will result in swelling of ligaments in the wrist area and that condition can press the nerves in the carpal tunnel [4]. Research in Hongkong showed there was a relationship between the duration of using hand devices such as mobile phones, tablets and game consoles with carpal tunnel syndrome among 500 Hongkong University students. More than 50 percent of students who use hand devices for more than 5 hours a day have Carpal Tunnel Syndrome Symptoms. This is due to the design of the device which produces a lot of hand movements such as tapping, swiping and scrolling which can cause dilation and flattening of the median nerve and thickening of the ligaments [9]. In addition there is rotation, deformity, and displacement of the median nerve in the carpal tunnel when using a mobile phone. This is believed to increase the risk of Carpal Tunnel Syndrome [10].

Another research showed there was no significant correlation between mobile phone use and Carpal Tunnel Syndrome. Significant risk factors for Carpal Tunnel Syndrome incidence were 
gender, age and BMI [11]. Carpal Tunnel Syndrome is common in old age. Increasing age causes exposure to work tools while working longer and the ability of bones elasticity, muscles or nerves decrease [12]. Women have a higher risk of Carpal Tunnel Syndrome than men. This situation occurs due to the influence of the estrogen in women. Estrogen plays a role in the regulation of fibroblast proliferation and collagen synthesis so that when the collagen composition of the tenosinovial tissue changes, the resistance of tissue will decrease. This will result in injury to the flexor tendons during finger movement. The alpha and beta estrogen receptors on fibroblasts and synovial cell layers in the tenosinovial have high immunoreactive properties so they are at greater risk of causing symptoms of Carpal Tunnel Syndrome. In addition, the size of women's hands and wrists is smaller than men. High Body Mass Index also affects the incidence of Carpal Tunnel Syndrome. This situation occurs due to the accumulation of fatty tissue around the carpal tunnel. In addition, obesity will cause edema in the nerve area which will lead to impaired conduction of the median nerve [13].

\section{Conclusion and Future Research}

There was a significant unidirectional correlation $(\mathrm{p}<0.0001)$ with a very weak correlation $(\mathrm{r}$ 0.177) between mobile phone use intensity and Carpal Tunnel Syndrome in medical Faculty North Sumatera University student batch 2017-2019. Future research can add variables such as position and hand movement as risk factors to assess the correlation between mobile phone use intensity and Carpal Tunnel Syndrome.

\section{REFERENCES}

[1] “Indonesia Digital 2019," Mar. 7, 2019. [Online]. Available: https://websindo.com/indonesia-digital-2019-tinjauan-umum/. [Accessed Mar. 7, 2020].

[2] Y.T. Chen, L. Williams, M.J. Zak, M. Fredericson,"Review of Ultrasonography in the Diagnosis of Carpal Tunnel Syndrome and a Proposed Scanning Protocol." J Ultrasound Med, vol. 35, no. 11, pp. 2311-2324. 2016.

[3] R. Mandias, H.M. Dengah, "Hubungan Intensitas Penggunaan Internet dengan Carpal Tunnel Syndrome." Klabat Journal of Nursing, vol. 1, no. 2, pp. 27. 2019.

[4] M.S. Aboong, "Pathophysiology Carpal Tunnel Syndrome," PubMed, Jan 2015. [Online]. Available: https://www.ncbi.nlm.nih.gov/pmc/articles/PMC4727604/. [Accessed Apr. 11, 2020].

[5] Allen, "Aren't you guilty of texting too much? just 5 hours on a mobile increases the risk of carpal tunnel syndrome," Jun. 22, 2017. [Online]. Available: http://www.google.co.id/amp/s/www.dailymail.co.uk/health/article4628506. [Accessed Mar. 28, 2020].

[6] Hermansyah, "Analisis Hubungan Intensitas Penggunaan Smartphone terhadap Kualitas Tidur Pelajar SMA Plus Shafiyyatul Amaliyyah Medan," Repository USU, Des. 4, 2018. 
[Online]. Available: http://repositori.usu.ac.id/handle/123456789/8810. [Accessed Apr. 12, 2020].

[7] C.I. Salsabila. "Karakteristik Individu dan Faktor Pekerjaan dengan Keluhan Carpal Tunnel Syndrome pada Pekerja Bagian Repair Veneer." Digital Repository Universitas Jember. $2019 \quad$ [Online]. Available: https://repository.unej.ac.id/bitstream/handle/123456789/97578/CINDY\%20ILA\%20SA BILA-152110101101.pdf?sequence=1\&isAllowed=y. [Accessed Apr. 11, 2020].

[8] J.M. Shim, "The Effect of Carpal Tunnel Changes on Smartphone Users." Journal of Physical Therapy Science, vol. 24, no. 12, pp. 1251-1253. 2016.

[9] A. Mozes, "Is Your Smartphone Giving You Carpal Tunnel?," Web MD [Internet]. Jun 21, 2017. [Online]. Available: https://www.webmd.com/pain-management/carpaltunnel/news/20170623/is-your-smartphone-giving-you-carpal-tunnel\#2. [Accessed Oct. 27, 2020].

[10] H.C. Woo, P. White, H.K. Ng, C.W.K. Lai, "Development of Kinematic Graphs of Median Nerve During Active Finger Motion: Implications of Smartphone Use." PLoS One. vol. 11, no. 7, pp. 1-17. 2016.

[11] A.S. Al Shahrani, S.S. Albogami, A.F. Alabdali, S.K. Alohali, H.S. Almedbal, G.F. Aldossary, "Does the use of electronic devices provoke the carpal tunnel syndrome (CTS) symptoms and functional impairment? A cross-sectional study." Egypt Rheumatol, vol. 41, no. 4, pp. 313. 2019.

[12] T. Pratiwi, F. Saftarina, A. Wahyuni, "Factors Affecting The Occurrence of Carpal Tunnel Syndrome ( CTS ) in Cleaning Workers of Onion Bark at Trade Unit Bawang Lanang Iringmulyo Metro City." Med J Lampung Univ, vol. 3, no. 4, pp. 138-45. 2014.

[13] S. Romlah, "Hubungan Indeks Massa Tubuh Dengan Menarche Dini." J Chem Inf Model, vol. 53, no. 9, pp. 1689-99. 2019. 